\title{
Diferensiasi Metode Penentuan Awal Bulan Hijriyah: Kajian Perspektif Teori Evolusi Sosial Herbert Spencer
}

\author{
M. Basthoni \\ Program Doktor (S3) Studi Islam Konsentrasi Falak \\ Universitas Islam Negeri Walisongo Semarang \\ Email: m.basthoni@gmail.com
}

\begin{abstract}
THE -- method of determining the beginning of the month of Hijrah is constantly differentiated. Several approaches have been made by experts to understand the phenomenon, both the socio-cultural comparison approach between the conditions of the Prophet Muhammad's time and the current conditions as well as the astronomicalnormative approach to verses that have been the root of these differences of opinion. In contrast to previous studies, this paper tries to find the pattern of the differentiation phenomenon and the background of the occurrence with the perspective of Social Evolution Theory proposed by Herbert Spencer. This study shows that the phenomenon of differentiation is a natural process that sequentially follows the following patterns and stages. (1) the stage of increasing the size, (2) the stage of the complexification, (3) the differentiation stage, and (4) the integration stage.
\end{abstract}

Keywords: Differentiation, Early Hijri Month, The Social Evolution Theory of Herbert Spencer

\section{Pendahuluan}

Proses evolusi metode penentuan awal bulan Hijriyah sampai sekarang masih terus berlangsung dan semakin terdiferensiasi. Hal ini dibuktikan dengan kompleksitas kalender Islam tersebut dari masa ke masa. Bahkan bisa dikatakan setiap kelompok dan aliran Islam yang ada sekarang masing-masing memiliki sistem penentuan awal bulan Hijriyah. Apa sebenarnya latar belakang dan bagaimana pola dari fenomena tersebut?

Kajian tentang penentuan awal bulan Islam ini mendapat perhatian cukup serius dari para ilmuan. Misalnya Susiknan Azhari dalam karyanya Hisab dan Rukyat: Wacana untuk Membangun Kebersamaan di Tengah Perbedaan secara khusus menyoroti terjadinya diferensiasi pemahaman tentang hadis rukyah antara kelompok hisab (Muhammadiyah) dan kelompok rukyah (Nahdlatul Ulama). ${ }^{1}$ Menurutnya, diferensiasi ini terjadi karena kedua kelompok tersebut memiliki latar belakang sosio-kultur yang mirip dengan masyarakat Mekah dan Madinah ketika hadis rukyah tersebut diucapkan oleh Nabi Muhammad SAW. Muhammadiyah, sebagaimana penduduk Mekah, berbasis masyarakat kota dan pedagang. Masyarakat Mekah lebih terbuka dan telah mengenal tradisi menghitung akibat kontak perdagangan dengan Parsi. Mereka memiliki pengetahuan dalam bidang astronomi walaupun masih sangat sederhana. ${ }^{2}$ Kesamaan kultur antara Muhammadiyah dan penduduk Mekah ini yang menurut Azhari menjadi

1 Susiknan Azhari, Hisab dan Rukyat: Wacana untuk Membangun Kebersamaan di Tengah Perbedaan, (Yogyakarta: Pustaka Pelajar, 2007), 53-71.

2 M. Quraish Shihab, Mukjizat Al-Qur'an, cet. II, (Bandung: Mizan, 1997), 72. 
salah satu latar belakang mengapa mengapa sampai saat ini Muhammadiyah menggunakan metode hisab dalam penentuan awal bulan Hijriyah. Berbeda dengan Mekah, Madinah merupakan daerah agraris dan subur ${ }^{3}$ sebagaimana letak geografis daerah-daerah basis Nahdlatul Ulama (NU). Hal ini, menurut Azhari, di kalangan NU makna rukyah cenderung dipahami dengan melihat dengan mata telanjang. Metode ini terus mengkristal di kalangan NU sehingga dikenal sebagai sampai saat ini NU dikenal sebagai madzhab rukyah dalam penentuan awal bulan Hijriyah.

Syamsul Anwar dalam bukunya Interkoneksi Studi Hadis dan Astronomi mencoba mengkombinasikan pendekatan normatif dan astronomis dalam mensikapi munculnya fenomena madzhab rukyah, hisab dan imkan ar-rukyat dalam penentuan awal bulan Hijriyah. ${ }^{4}$ Dalam kajiannya tersebut ia menyimpulkan bahwa pemahaman hadis-hadis rukyah tidak cukup dengan pendekatan teks namun juga harus dilihat dari keseluruhan semangat al-Qur'an yang memperhatikan ilat (kausa hukum) dalam perintah rukyah dalam hadis-hadis Nabi SAW tersebut. Maka dengan ini, hisab dapat diterima dan sesuai semangat umum al-Qur'an. Dengan pendekatan astronomis ia menambahkan bahwa penggunaan rukyah dapat menyebabkan kawasan zona waktu barat pada Zulhijjah tertentu tidak dapat melaksanakan puasa Arafah karena hari Arafah di Mekah jatuh bersamaan dengan hari Idul Adha di zona ujung barat. Begitu pula problem juga bisa timbul bagi mereka yang berada di zona ujung timur di mana hari Arafah di Mekah bisa jatuh pada Zulhijah tertentu pada tanggal 8 Zulhijah menurut zona bersangkutan. Dengan reasoning tersebut, Syamsul Anwar merekomendasikan penggunaan metode hisab untuk penyatuan kelender Hijriyah Internasional.

Berbeda dengan pendekatan yang dilakukan dalam dua kajian tersebut, tulisan ini akan mencoba menguraikan lebih jauh tentang fenomena diferensiasi perbedaan metode penetapan awal bulan Islam ini menggunakan pendekatan ilmu-ilmu sosial khususnya teori evolusi sosial Herbert Spencer. Diharapkan dengan pendekatan yang digunakan ini bisa digambarkan latar belakang dan pola diferensiasi tersebut.

Uraian singkat tentang teori evolusi sosial Herbert Spencer menjadi awal pembahasan tulisan ini sebagai pijakan untuk menganalisa fenomena munculnya berbagai metode penentuan awal bulan Hijriyah. Dilanjutkan uraian proses perkembangan sistem kalender umat Islam dalam perspektif teori evolusi sosial tersebut. Dengan alur ini diharapkan muncul simpulan tentang apa latar belakang dan bagaimana pola sistem kalender umat Islam tersebut.

\section{Sekilas tentang Herbert Spencer}

Herbert Spencer (1820-1903) adalah ilmuan Inggris yang ahli di bidang biologi, sosiologi, dan ahli teori politik liberal. Sebagai orang yang menekuni banyak bidang, Spencer mencoba mengembangkan suatu konsep bahwa evolusi merupakan perkembangan progresif yang meliputi berbagai hal, baik aspek biologis organisme maupun pemikiran dan kebudayaan manusia dan masyarakat. Spencer sangat terpikat

${ }^{3}$ Frederick M. Denny, "Islam and Muslim Communities" dalam H. Byron Eahast, Religious Traditions of the World, (California: Harfes San Fransisco Collins Publisher, 1993), 623-628.

4 Syamsul Anwar, Interkoneksi Studi Hadis dan Astronomi, (Yogyakarta: Suara Muhammadiyah, 2011), 181-207. 
dengan evolusinisme. Bahkan ia cukup dikenal sebagai "Social Darwinism" 5 yang juga punya kontribusi dalam pengembangan beberapa bidang pengetahuan yang lain di antaranya adalah bidang sosiologi, antropologi, ekonomi, politik, etika, agama, filsafat, biologi, dan psikologi. ${ }^{6}$

\section{Teori Evolusi sosial}

Konsep evolusionisme dalam bidang biologi diusulkan dan digunakan oleh Darwin, sedangkan Spencer sangat antusias menggunakan konsep evolusi dalam bidang sosiologi. Menurut Spencer proses evolusi sosial dimulai dari evolusi individu-individu yang menggabungkan diri menjadi sebuah keluarga, keluarga bergabung menjadi komunitas, komunitas menjadi masyarakat, dan masyarakat menjadi negara, dan demikian seterusnya.

First Principles (1862) adalah salah satu karya monumental Spencer. Ia menyatakan bahwa masyarakat harus berpegang pada prinsip ketahanan kekuatan (the law of the persistence of force), yaitu bahwa yang kuatlah yang akan bertahan. Konsepsi Spencer tentang evolusi sosial adalah bagian dari konsepsinya yang lebih general tentang evolusi alam semesta. ${ }^{7}$

Dalam bukunya yang berjudul Social Statics, ${ }^{8}$ Spencer mengatakan bahwa masyarakat merupakan organisme, dalam perspektif positivistis dan deterministis. Hukum alam bisa dijadikan dasar untuk menjelaskan semua fenomena sosial. Menurut Spencer, sebagaimana hukum alam yang menentukan proses evolusi tubuh biologis manusia, hukum alam juga menjadi penentu proses evolusi sosial.

Lebih lanjut Spencer berpendapat bahwa masyarakat merupakan organisme otonom dan berevolusi secara mandiri tanpa keinginan atau arahan dari masing-masing anggotanya sesuai dengan hukum alam. Misalnya, seseorang dengan segala kekurangannya tentu sangat kesulitan untuk bisa bertahan tanpa bantuan orang lain. Untuk melengkapi kekurangan masing-masing individu terdorong untuk bergabung dengan orang lain.

Menurut Spencer ada empat tahap evolusi sosial: pertama, tahap peningkatan ukuran. Secara bertahap sebuah organisme akan berkembang ukurannya sebagaimana masyarakat akan berkembang dari segi jumlah dan ukurannya. Kedua, tahap kompleksifikasi. Setelah melalui proses peningkatan ukuran, struktur sebuah organisme akan semakin kompleks sebagaimana struktur organisasi sosial semakin lama juga semakin kompleks. Ketiga, tahap diferensiasi. Salah satu akibat dari evolusi sosial adalah adanya pembagian tugas atau fungsi yang semakin beragam (deferensiasi). Pembagian kerja dan fungsi ini menyebabkan adanya pelapisan sosial (stratifikasi). Selanjutnya masyarakat terbagi ke dalam kelas-kelas sosial. Keempat, tahap integrasi. Adanya diferensiasi diduga menyebabkan munculnya perpecahan. Untuk itu harus ada proses untuk menanggulangi perpecahan ini dan proses integrasi. Tahap integrasi ini juga

\footnotetext{
5 Gregory Claeys, "The 'Survival of the Fittest' and the Origins of Social Darwinism", Journal of the History of Ideas, 2000, 61 (2): 223-40, doi:10.1353/jhi.2000.0014

6 David Duncan, The Life and Letters of Herbert Spencer, (London: William \& Norgate, 1911), 53-55. 1862).

7 Uraian lengkap bisa dibaca dalam Herbert Spencer, First Principles, (London: William and Norgate,

${ }^{8}$ Lebih detail baca Herbert Spencer, Social Statics Abridged and Revised Together with the Man Versus the State, London: William and Norgate, 1892).
} 
merupakan salah satu tahap dalam proses evolusi. Proses ini bersifat natural, spontan dan otomatis tanpa rekayasa agar intergrasi menuju keseimbangan ini berjalan dengan baik. Manusia sebagai anggota masyarakat tidak perlu melakukan usaha yang terlalu ekstrim untuk terwujudnya proses integrasi ini. ${ }^{9}$

\section{Proses Diferensiasi Sistem Kalender Umat Islam}

Sebagaimana diuraikan di atas bahwa teori evolusi Spencer menjelaskan bahwa struktur dan fungsi masyarakat terdiferensiasi dari yang awalnya bersifat homogen menjadi heterogen, dari yang sederhana menjadi kompleks, dan seterusnya. Teori ini akan dicoba diterapkan dalam ranah struktur pemikiran bukan pada terdiferensiasinya struktur dan fungsi dalam masyarakat. Karena ada satu pola gerak pemikiran dari yang bercorak sederhana menjadi bersifat kompleks, dari hanya satu jenis pemikiran (homogen) menjadi banyak jenis pemikiran, heterogen. Kemudian muncul diferensiasi dalam pemikiran. Kemudian pemikiran yang telah terspesialisasi ini terus berkembang, masing-masing pemikiran dengan yang berbeda-beda ini kemudian menyatukan diri menjadi kelompok tersendiri. Dari kelompok yang telah menyatu ini kemudian muncul spesialisasi lagi, dan juga berkembang, kemudian membentuk kelompok yang baru dan demikian seterusnya. Untuk itu tulisan ini akan mencoba menerapkan teori evolusi sosial Herbert Spencer dalam ranah pemikiran tentang metode penetapan awal bulan Islam dalam sejarah sosial umat Islam.

Pada awal berkembangan sistem kalender Islam, yaitu pada masa Nabi Muhammad SAW.10, metode yang digunakan dalam penentuan awal bulan cukup sederhana yaitu dengan melihat Bulan sabit. Jika Bulan sabit terlihat di saat terbenam Matahari maka keesokan hari ditetapkan sebagai bulan baru, dan jika Bulan tidak terlihat atau tertutup mendung maka ditetapkan dua hari kemudian sebagai bulan baru.

Metode yang digunakan mengalami sedikit perubahan pada masa Umar bin Khattab. Pada masa tersebut sistem sosial dan politik telah berkembang. Urusan-urusan dalam masyarakat atau pemerintahan membutuhkan penanda waktu yang pasti. Jika masih menggunakan metode menunggu terlihat atau tidaknya hilal tentu sangat kesulitan untuk penentuan waktu yang pasti.

Untuk menjawab permasalah tersebut khalifah Umar bin Khattab membentuk tim untuk merumuskan kalender yang bersifat matematis yang kemudian dirumuskan kalender disebut kalender hisab adadi, atau, yang berpatokan pada umur rata-rata bulan qomariyah yaitu antara 29-30.11 Kalender Umar ini dikenal dengan nama kalender urfi dan mulai berlaku pada abad 17 H. ${ }^{12}$

${ }^{9}$ Ritzer George, Teori Sosiologi Modern, terj. Alimandan, (Jakarta: Kencana, 2007), 50-51.

10 Nabi bersabda:

أن رسول الله صلى الله عليه وسلم ذكر رمضان فقال لاتصوموا حتى تروا الهلال و لاتفطروا حتى تروه فإن غم عليكم فاقدروا له

Sesungguhnya Rasul Allah Saw.menyebut-nyebut Ramadan kemudian bersabda, "janganlah kalian berpuasa sehingga kalian melihat hilal (tanggal satu Ramadan). Dan janganlah kalian berhari raya sehingga kalian melihatnya (tanggal satu Syawal). Apabila (cuaca dilangit menjadikan bulan) terlindung dari (pemandangan) kalian, maka kadarkanlah. Muhammad ibn Isma'il Abu Abdillah al-Bukhari, al-Maktabah al-Syamilah, Edisi Kedua, t.t. Hadis no. 1807.

${ }^{11}$ Muhyiddin Khazin, Ilmu Falak dalam Teori dan Praktik, (Yogyakarta: Buana Pustaka, 2004), 110.

12 Kalender Hijriyah ditentukan oleh Umar bin Khattab pada tahun 17 H. Pendapat lain menyebutkan pada tahun $16 \mathrm{H}$ dan $18 \mathrm{H}$. Tetapi yang masyhur adalah pada tahun $17 \mathrm{H}$. Uraian selengkapnya baca $\mathrm{H}$. AR. 
Jadi sejak masa pemerintahan Umar ada dua sistem kalender Islam. Pertama untuk keperluan ibadah tetap berpatokan pada penglihatan terhadap bulan sabit sebagaimana diajarkan oleh Nabi Muhammad SAW. Kedua, untuk menjamin kepastian penentuan penanda waktu dalam kehidupan sosial-politik digunakan pedoman pada umur rata-rata bulan. Menurut kacamata teori evolusi Spencer, peristiwa ini adalah awal proses terjadinya diferensiasi dari yang awalnya homogen dan sederhana (hanya berpatokan pada penglihatan pada Bulan sabit), kemudian menjadi sedikit kompleks karena ada sistem kalender baru yang menggunakan perhitungan matematis.

Penggunaan hisab untuk penentuan awal bulan Hijriyah terus berkembang pada masa tabi'in tepatnya dicetuskan oleh Mutarrif bin Abdullah. Bermodalkan pemahaman terhadap fase-fase bulan, Muttarif memahami kata 'perkirakan' dalam hadits tentang awal Ramadlan dengan makna menghitung fase-fase bulan. Ini lah embrio munculnya pendapat yang memahami bahwa hisab bisa dijadikan pedoman penentuan awal bulan hijriyah di saat cuaca mendung. ${ }^{13}$

Ilmu terus berkembang seiring interaksi umat Islam terhadap ilmuan Barat khususnya ilmu yang bersumber dari Yunani. Seiring perkembangan tersebut ilmu falak (astronomi) mulai dikenal di dunia Islam ${ }^{14}$ serta semakin menguat diskursus pemahaman tentang boleh tidaknya menentukan awal bulan Islam untuk keperluan ibadah dengan menggunakan perhitungan astronomis. Maka sejak itu, muncullah dua kelompok umat Islam, yang satu memperbolehkan penggunaan ilmu hisab dengan perhitungan astronomis sebagai metode penentuan awal bulan Islam untuk keperluan ibadah, sedangkan kelompok lainnya tidak memperbolehkan metode hisab tersebut dan tetap berpedoman dengan rukyat bil fi'li (melihat dengan mata telanjang) sebagai sunnah fi'liyah yang dicontohkan oleh Nabi Muhammad SAW. Hal tersebut memicu munculnya spesialisasi pemikiran dalam penentuan awal bulan Islam ada yang beraliran rukyat dan ada yang beraliran hisab serta masing-masing selalu bersaing untuk bertahan (survive). Tanpa disadari proses ini yang selanjutnya terus menambah kompleksitas kalender Islam.

Permasalahan semakin kompleks setelah munculnya gerakan sufistik umat Islam yang mulai tergerak untuk mempertajam mata batin. Salah satu fenomena yang menarik adalah bahwa ada di antara umat Islam yang menggunakan mata batin untuk menentukan kapan dimulainya puasa, misalnya Thariqah Syatthariyyah 15

Diferensiasi tidak berhenti dan bahkan terus berkembang di dalam masing-masing aliran. Kelompok pendukung rukyah terdiferensiasi menjadi beberapa kelompok. Pertama, kelompok rukyah murni, kelompok ini menerapkan rukyah sebagaimana adanya tanpa disertai dengan pertimbangan lain. Rukyah bisa diterima jika perukyah seorang muslim dan mau disumpah. Salah satu aliran yang mewakili kelompok ini adalah Hizbut Tahrir Indonesia (HTI). ${ }^{16}$ Kedua, kelompok yang diwakili oleh Nahdlatul Ulama (NU)

Gibb dan J. H. Kramers, Shorter Encyclopedia of Islam, (Leiden: E.J. Brill, 1961), 139. Lihat juga E.J. Brill's, First Encyclopedia of Islam, cet. I, (London: Stacy International, 1989), 456.

13 Salman Alfarisi, "Analisis Metode Penetapan Awal Bulan Kamariah Perspektif Empat Mazhab", Sinopsis Tesis, (Semarang: Institut Agama Islam Negeri Walisongo Semarang, 2013), 23.

14 Moh. Murtadho, Ilmu Falak Praktis, (Malang: UIN Malang Press, 2008), 22-23.

15 Ilham Nadhirin, “Penentuan Awal Bulan Islam Dalam Ajaran Thariqah Syatthariyyah (Studi di Desa Setono Kecamatan Ngrambe Kabupaten Ngawi Jawa Timur)", Sinopsis Skripsi, (Malang: Fakultas Sari'ah UIN Maulana Malik Malang, 2013), 9.

16 Jumiatil Huda, "Penentuan Awal Bulan Qamariyah dalam Perspektif Hizbut Tahrir", Skripsi, (Jakarta: UIN Syarif Hidayatullah, 2011), 70. 
yang mengusung pemahaman rukyah dengan didukung ilmu hisab. Kelompok ini menolak hasil rukyah jika bertentangan dengan hasil hisab. ${ }^{17}$ Ketiga, adalah kelompok rukyat non-mainstream, contohnya jamaah Naqsabandiyah Sumatera Barat yang menggunakan rukyah bulan tanggal 8, 15, dan 8 hari sebelum akhir bulan, dan bukan rukyat hilal (bulan sabit).18 Di samping terbagi menjadi 3 (tiga) kelompok tersebut, kelompok rukyah juga terdiferensiasi menjadi rukyah Global dan rukyah Regional. ${ }^{19}$

Sebagaimana kelompok rukyah, kelompok pendukung hisab astronomis seiring perkembangan sains dan teknologi juga terdiferensiasi menjadi beberapa kelompok. Pertama, kelompok yang dinahkodai oleh organisasi Muhammadiyah yang mengusulkan kriteria wujudul hilal. ${ }^{20}$ Kedua, kelompok yang diwakili oleh organisasi Persatuan Islam (PERSIS) yang mendukung kriteria imkan al-rukyah. ${ }^{21}$ Ketiga, kelompok pendukung kriteria ijtima' (kongjungsi).

Tidak berhenti di sini, kelompok terakhir dari 3 (tiga) kelompok rukyah di atas yaitu kelompok kriteria ijtima' terdiferensiasi menjadi kelompok ijtima' qobla al-ghurub, ijtima' qabla thulu' al-fajr, ijtima' qabla zawal al-syams, dan ijtima' qobla nisf al-lail.22 Salah satu komunitas yang menggunakan kriteria ijtima' adalah Negara Arab Saudi dalam kalender sipilnya yang disebut dengan kalender Ummul Quro. ${ }^{23}$

Dalam penelusuran sejarah, ditemukan bahwa yang mengalami diferensiasi tidak hanya kelompok pendukung hisab astronomis, namun hal tersebut juga terjadi dalam kelompok pendukung hisab matematis yang tidak menggunakan pergerakan bendabenda langit sebagai objek perhitungan, melainkan umur rata-rata bulan qomariyah. Contoh dari aliran ini adalah jamaah Tarekat Naqsabandiyah di Sumatera Barat yang menggunakan metode Hisab Munjid ${ }^{24}$ dan Jamaah Islam Aboge yang menggunakan sistem perhitungan kalender Jawa-Islam. ${ }^{25}$

17 Ahmad Ghazalie Masroeri, Penentuan Awal Bulan Qamariyah Perspektif NU, http:/ / www.nu.or.id/post/read/9618/ penentuan-awal-bulan-qamariyah-perspektif-nu, diakses 7 Mei 2018.

18 Rudi Kurniawan, "Studi Analisis Penentuan Awal Bulan Kamariah dalam Perspektif Tarekat Naqsabandiyah di Kota Padang", Skripsi, (Semarang: Institut Agama Islam Negeri Walisongo Semarang, 2013), 56.

19 Imron Rosyadi, Matlak Global dan Regional (Studi tentang Keberlakuan Rukyat Menurut Fikih dan Astronomi), Conference Proceeding Annual International Conference of Islamic Studier XII, 2515-2517.

${ }^{20}$ Rahmadi Wibowo Suwarno, “Menelisik Metodologi Hisab -Falak Muhammadiyah; Studi HistorisKomparatif", Makalah dipresentasikan dalam acara Simposium Terbuka Majelis Tarjih (PCIM) Kairo, "Revitalisasi Ilmu Falak dalam Penentuan Awal Bulan Hijriyah", di Auditorium Griya Jawa Tengah, Ahad 09 September 2007 M/26 Sya'ban 1428 H.

${ }^{21}$ Ai Siti Wasilah, “Dinamika Kriteria Penetapan Awal Bulan Kamariah”, Skripsi, (Jakarta: UIN Syarif Hidayatullah, 2015), 73.

22 Jaenal Arifin, "Fiqih Hisab Rukyah di Indonesia (Telaah Sistem Penetapan Awal Bulan Qamariyyah)", YUDISIA, Vol. 5, No. 2, Desember 2014, 413.

${ }_{23}$ Syamsul Anwar, Zulhijah, Tahun Baru Hijriah dan Kalender Islam Global, http:/ / www.muhammadiyah.or.id/id/content-153-det-zulhijah-tahun-baru-hijriah-dan-kalender-islamglobal.html, diakses 7 Mei 2018.

24 Rudi Kurniawan, “Studi Analisis Penentuan Awal.", 54-61.

25 Jamaah Islam Aboge atau Alif-Rebo-Wage (A-bo-ge) adalah pengikut ajaran Raden Rasid Sayid Kuning. Perhitungan yang didigunakan oleh jamaah Aboge adalah metode yang telah digunakan para wali tanah Jawa sejak abad ke-14 yang kemudian dipopulerkan oleh ulama Raden Rasid Sayid Kuning dari kerajaan Pajang. Menurut sistem perhitungan kalender Jamaah Islam Aboge ada siklus delapan tahunan atau satu windu yang terdiri dari tahun Alif, Ha, Jim Awal, Za, Dal, Ba/Be, Wawu, dan Jim Akhir. Dalam satu tahun terdiri 12 bulan dan masing-masing bulan terdiri dari 29-30 hari. Ada hari pasaran menurut perhitungan kalender Jawa, yaitu Pon, Wage, Kliwon, Legi, dan Pahing. Hari dan pasaran pertama pada 
Sebagaimana diuraikan sebelumnya, dalam aliran muncul aliran rukyat ditemukan non-mainstream. Hal ini juga ditemukan dalam aliran hisab. Misal di Indonesia muncul aliran seperti kelompok Jama'ah an-Nadzir yang menggunakan pasang surut air laut dan menerawang dengan kain hitam sebagai patokan penentuan awal bulan Islam. ${ }^{26}$

Ditinjau dari teori Spencer, diferensiasi umat Islam terkait sistem kalender khususnya dalam penentuan awal bulan Hijriyah merupakan proses alami sesuai hukum alam. Menurut teori Spencer tersebut, hal ini dianggap wajar karena masing-masing kelompok berusaha mempertahankan metode yang diyakini supaya tetap survive dan tetap eksis dalam belantara dan kancah dinamika penentuan awal bulan Hijriyah.

\section{Proses Integrasi Sistem Kalender Umat Islam}

Menurut teori Spencer, proses evolusi sistem kalender Islam masuk pada proses integrasi. Usaha untuk melakukan unifikasi kalender Islam mulai marak dilakukan. Dalam catatan sejarah, usaha ini terus dilakukan oleh para ahli ilmu falak maupun otoritas pemerintah. Usaha yang dilakukan oleh para ahli falak adalah seputar penentuan kriteria yang diterima bersama dan batas keberlakukan dan garis tanggal. ${ }^{27}$

BHR (Badan Hisab Rukyat) yang dibentuk pada masa Presiden Soeharto dengan SK Menteri Agama (H.A. Mukti Ali) nomor 76 tahun 1972 tertanggal 16 Agustus 1972 merupakan salah satu usaha untuk menyatukan perbedaan dalam penentuan awal bulan hijriyah yang sering sering terjadi di kalangan umat Islam Indonesia. Usaha ini dilakukan demi stabilitas nasional. Dalam sambutan pengarahannya Menteri Agama mengatakan bahwa: Badan Hisab dan Rukyat ini diadakan berdasarkan pertimbangan bahwa: pertama, masalah hisab dan rukyat awal bulan qamariyah merupakan masalah penting dalam menentukan hari-hari besar Islam. Kedua, hari-hari besar itu erat hubungannya dengan peribadatan umat Islam, dengan hari libur, dengan hari kerja, dengan lalu lintas keuangan dan kegiatan ekonomi di negeri kita ini, juga erat hubungannya dengan pergaulan hudup kita, baik antara umat Islam sendiri maupun antara umat Islam dengan saudara-saudara sebangsa setanah air. Ketiga, persatuan umat Islam dalam melaksanakan peribadatan perlu diusahakan, karena ternyata perbedaan pendapat yang menimbulkan pertentangan itu dapat melumpuhkan umat Islam dalam partisipasinya dalam membangun bangsa dan negara. ${ }^{28}$

tahun Alif jatuh pada hari Rabu Wage (Aboge), tahun Ha pada Ahad/Minggu Pon (Hakadpon), tahun Jim Awal pada Jumat Pon (Jimatpon), tahun Za pada Selasa Pahing (Zasahing), tahun Dal pada Sabtu Legi (Daltugi), tahun Ba/Be pada Kamis Legi (Bemisgi), tahun Wawu pada Senin Kliwon (Waninwon), dan tahun Jim Akhir pada Jumat Wage (Jimatge)., Islam Aboge Ajaran Warisan Raden Rasid Sayid Kuning. Selengkapnya baca : M. Alfatih Husain, "Komunitas Islam Aboge (Penerapan antara Sistem Kalender dengan Aktifitas Sosial Keagamaan di Desa Onje Kecamatan Mrebet Kabupaten Purbalingga)", Skripsi, (Yogyakarta: UIN Sunan Kalijaga, 2015).

${ }^{26}$ Hesti Yozevta Ardi, "Metode Penentuan Awal Bulan Kamariyah Menurut Jama'ah Annazir”, Skripsi (Semarang: Institut Agama Islam Negeri Walisongo Semarang, 2012), 92.

27 Syamsul Anwar, Menyatukan Sistem Islam, http://www.muhammadiyah.or.id/muhfile/download/kalender_islam_falak/MENYATUKAN SISTEM PENANGGALAN ISLAM Edit.pdf, diakses 8 Mei 2018.

28 Adapun tugas-tugas BHR sebagaimana disebutkan dalam SK Menteri Agama no 76 tahun 1972 diktum Kedua berbunyi: Tugas Badan Hisab dan Rukyat ialah memberikan saran-saran kepada Menteri Agama dalam penentuan permulaan tanggal bulan-bulan qamariyah. Lihat Muhyiddin Khazin, 99 Tanya Jawab Masalah Hisab Rukyat, (Yogyakarta: Ramadhan Press, 2009), 100-101. 
Namun fungsi pembentukan Badan Hisab Rukyat tersebut masih jauh dari tujuan dibentuknya badan tersebut. Mayoritas organisasi-organisasi Islam di Indonesia memilih menaati ikhbar dari pemimpin organisasinya dibandingkan harus mengikuti arahan pemerintah via BHR. Sehingga cukup masuk akal ketika ada usulan pembubaran lembaga tersebut pada pada pemerintahan Presiden Gus Dur dan mengembalikan otoritas penentuan awal bulan Islam kepada umat Islam. ${ }^{29}$

Namun proses integrasi terus bergulir karena pada dasarnya, umat Islam menginginkan adanya Kelnder Hijriah tunggal yang dapat dipakai semua muslim di seluruh penjuru dunia. Keinginan ini sudah sejak lama digagas, seiring dengan kemajuan teknologi yang memungkinkan penduduk bumi bisa berkomunikasi secara real time. Unifikasi tanggal hijriah dengan prinsip pada hari yang sama mempunyai tanggal yang sama telah muncul sejak satu hari satu tanggal di seluruh dunia, sudah diinisiasi pada tahun 1939 oleh ulama Mesir, Aḥmad Muhammad Syākir.30

Pada 28-30 Mei 2016 diadakan kongres internasional penyatuan kalender hijriah yang diselenggarakan oleh Badan Urusan Keagamaan Turki (Presidency of Religious Affairs), disepakati kalender tunggal untuk sistem kalender Global. Dengan kriteria (1) imkanu rukyat 5-8 (tinggi hilal minimal 5 derajat, elongasi 8 derajat) di suatu tempat di seluruh dunia sebelum pukul 12 malam GMT. Atau 2). Imkanu rukyat terjadi sebelum fajar di Selandia Baru. Kriteria masih diperlukan pengujian lebih lanjut. ${ }^{31}$

Pada 30 November 2017, sebagai kelanjutan dari konggres di Turki, dalam seminar International Fikih Falak di Jakarta merekomendasikan kriteria Istanbul Turki 2016 dengan melakukan modifikasi menjadi kriteria elongasi minimal 6,4 derajat dan tinggi minimal 3 derajat dengan markaz Kawasan Barat Asia Tenggara. ${ }^{32}$

Dalam kaca mata teori evolusi Spencer, ketidaknyamanan umat Islam selalu berbeda pendapat dalam penentuan awal bulan Islam membuka kesadaran masingmasing kelompok untuk berdiskusi secara intensif dan masif mencari dan menemukan titik temu melalui berbagai forum diskusi dan konggres baik secara nasional, regional maupun internasional. Memang sampai saat ini belum ditemukan titik temu yang disepakati semua pihak namun setidaknya semua pihak sudah mulai membuka diri untuk berdialog untuk mencari titik temu.

\section{Simpulan}

Dalam pandangan Herbert Spencer masyarakat berevolusi menuju diferensiasi merupakan hukum alam yang berjalan alami sesuai dengan hukum alam tersebut. seleksi alam tersebut direspon oleh umat Islam agar tetap survive. Hal ini juga ditemukan dalm perkembangan sistem kalender Islam. Sistem kalender yang diajarkan Nabi Muhammad SAW khususnya dalam penentuan awal bulan Islam pada perkembangannya

29 Ahmad Izzuddin, Fikih Hisab Rukyat, Menyatukan NU \& Muhammadiyah dalam Penentuan Awal Ramadhan, Idul Fitri dan Idul Adha, (Jakarta: Erlangga, 2007), 59.

30 Lebih jelas baca Makrifat Iman, Kalender Pemersatu Dunia Islam, (Jakarta: Gaung Persada Press, 2010).

31 Khafid, "Historis Penerapan Garis tanggal Masehi sebagai Pembelajaran untuk Langkah Implementasi Konsep Kalender Hijriah Global Tunggal", makalah disampaikan dalam Halaqah Ahli Hisab Muhammadiyah, Majelis Tarjih Dan Tajdid Pimpinan Pusat Muhammadiyah, Yogyakarta, Sabtu-Ahad, 19-20 Syakban 1439 H / 5-6 Mei 2018 M.

32 Thomas Djamaluddin, "Proposal Ringkas Penyatuan Kalender Islam Global”, makalah disampaikan dalam seminar International Fikih Falak di Jakarta, 30 November 2017. 
berkembang menjadi dua aliran utama: hisab dan rukyat. Masing-masing aliran sekuat tenaga mempertahan metode yang diyakini supaya tetap eksis dalam kancah diskursus metode penentuan awal bulan Hijriyah. Karena itu merupakan hal yang tidak mudah untuk menyatukan sistem kalender umat Islam. Namun demikian berbeda pendapat secara terus menerus dalam jangka waktu yang cukup panjang menimbulkan rasa kurang nyaman yang dirasakan masing-masing kelompok sedikit banyak memiliki andil usaha yang dilakukan oleh kelompok yang berbeda pendapat untuk terus berusaha melakukan proses integrasi dan penyatuan kalender Islam.

\section{Daftar Pustaka}

Alfarisi, Salman. 2011. Analisis Metode Penetapan Awal Bulan Kamariah Perspektif Empat Mazhab. Sinopsis Tesis. Semarang: Institut Agama Islam Negeri Walisongo Semarang

Anwar, Syamsul. 2011. Interkoneksi Studi Hadis dan Astronomi. Yogyakarta: Suara Muhammadiyah

--------, 2018. Menyatukan Sistem Penanggalan Islam, http://www.muhammadiyah.or.id/ muhfile/ download/kalender_islam_falak/ MENYATUKAN SISTEM PENANGGALAN ISLAM Edit.pdf, diakses 8 Mei 2018.

-------, 2018. Zulhijah, Tahun Baru Hijriah dan Kalender Islam Global, http://www.muhammadiyah.or.id /id/content-153-det-zulhijah-tahun-baruhijriah-dan-kalender-islam-global.html, diakses 7 Mei 2018.

Ardi, Hesti Yozevta. 2012. Metode Penentuan Awal Bulan Kamariyah Menurut Jama'ah Annazir. Skripsi. Semarang: Institut Agama Islam Negeri Walisongo Semarang

Arifin, Jaenal. 2014. Fiqih Hisab Rukyah di Indonesia (Telaah Sistem Penetapan Awal Bulan Qamariyyah). YUDISIA, Vol. 5, No. 2, Desember 2014.

Azhari, Susiknan. 2017. Hisab dan Rukyat: Wacana untuk Membangun Kebersamaan di Tengah Perbedaan. Yogyakarta: Pustaka Pelajar

Brill's, E.J. 1989. First Encyclopedia of Islam, cet. I. London: Stacy International

Claeys, Gregory. 2000. The 'Survival of the Fittest' and the Origins of Social Darwinism, dalam Journal of the History of Ideas, 2000, 61 (2): 223-40, doi:10.1353/jhi.2000.0014

Djamaluddin, Thomas. 2017. Proposal Ringkas Penyatuan Kalender Islam Global. Makalah disampaikan dalam seminar International Fikih Falak di Jakarta, 30 November 2017.

Denny, Frederick M. 1993. "Islam and Muslim Communities" dalam H. Byron Eahast, Religious Traditions of the World, (California: Harfes San Fransisco Collins Publisher). 
Endogami: Jurnal Ilmiah Kajian Antropologi

E-ISSN : 2599-1078

Duncan, David. 1911. The Life and Letters of Herbert Spencer. London: William \& Norgate.

George, Ritzer, 2007. Teori Sosiologi Modern, terj. Alimandan. Jakarta: Kencana

Gibb, H. AR. \& J. H. Kramers. 1961. Shorter Encyclopedia of Islam. Leiden: E.J. Brill

Huda, Jumiatil, 2001. Penentuan Awal Bulan Qamariyah dalam Perspektif Hizbut Tahrir. Skripsi. Jakarta: UIN Syarif Hidayatullah

Husain, M. Alfatih. 2015. Komunitas Islam Aboge (Penerapan antara Sistem Kalender dengan Aktifitas Sosial Keagamaan di Desa Onje Kecamatan Mrebet Kabupaten Purbalingga). Skripsi. Yogyakarta: UIN Sunan Kalijaga

Iman, Makrifat. 2010. Kalender Pemersatu Dunia Islam. Jakarta: Gaung Persada Press

Izzuddin, Ahmad. 2007. Fikih Hisab Rukyat, Menyatukan NU \& Muhammadiyah dalam Penentuan Awal Ramadhan, Idul Fitri dan Idul Adha. Jakarta: Erlangga

Khafid, 2018. "Historis Penerapan Garis tanggal Masehi sebagai Pembelajaran untuk Langkah Implementasi Konsep Kalender Hijriah Global Tunggal", makalah disampaikan dalam Halaqah Ahli Hisab Muhammadiyah, Majelis Tarjih Dan Tajdid Pimpinan Pusat Muhammadiyah, Yogyakarta, Sabtu-Ahad, 19-20 Syakban 1439 H / 5-6 Mei 2018 M.

Khazin, Muhyiddin. 2009. 99 Tanya Jawab Masalah Hisab Rukyat. Yogyakarta: Ramadhan Press

--------, 2004. Ilmu Falak dalam Teori dan Praktik. Yogyakarta: Buana Pustaka

Kurniawan, Rudi. 2013. "Studi Analisis Penentuan Awal Bulan Kamariah dalam Perspektif Tarekat Naqsabandiyah di Kota Padang", Skripsi. Semarang: Institut Agama Islam Negeri Walisongo Semarang

Masroeri, Ahmad Ghazalie. 2018. Penentuan Awal Bulan Qamariyah Perspektif NU, http://www.nu.or.id/post/read/9618/ penentuan-awal-bulan-qamariyahperspektif-nu, diakses 7 Mei 2018.

Murtadho, Moh. 2008. Ilmu Falak Praktis. Malang: UIN Malang Press, 2008

Nadhirin, Ilham. 2013. "Penentuan Awal Bulan Islam Dalam Ajaran Thariqah Syatthariyyah (Studi di Desa Setono Kecamatan Ngrambe Kabupaten Ngawi Jawa Timur)". Sinopsis Skripsi. Malang: Fakultas Sari'ah UIN Maulana Malik Malang

Shihab, M. Quraish, 1997. Mukjizat Al-Qur'an, cet. II. Bandung: Mizan

Spencer, Herbert. 1862. First Principles. London: William and Norgate 
Endogami: Jurnal Ilmiah Kajian Antropologi

E-ISSN : 2599-1078

1892. Social Statics Abridged and Revised Together with the Man Versus the State, London: William and Norgate

Suwarno, Rahmadi Wibowo. 2007. "Menelisik Metodologi Hisab-Falak Muhammadiyah; Studi Historis-Komparatif", Makalah dipresentasikan dalam acara Simposium Terbuka Majelis Tarjih (PCIM) Kairo, "Revitalisasi Ilmu Falak dalam Penentuan Awal Bulan Hijriyah", di Auditorium Griya Jawa Tengah, Ahad 09 September 2007 M/26 Sya'ban $1428 \mathrm{H}$.

Wasilah, Ai Siti. 2015. Dinamika Kriteria Penetapan Awal Bulan Kamariah. Skripsi. Jakarta: UIN Syarif Hidayatullah 